\title{
EFFECT OF PRIMING OF SEEDS OF MEDICAGO SATIVA 'BAMI' WITH GIBBERELLIC ACID ON GERMINATION, SEEDLINGS GROWTH AND ANTIOXIDANT ENZYMES ACTIVITY UNDER SALINITY STRESS
}

\author{
Omid YOUNESI ${ }^{1 *}$, Ali MORADI ${ }^{2}$ \\ ${ }^{1}$ University of Tehran, Iran \\ ${ }^{2}$ Yasouj University, Yasouj, Iran \\ Received: August 7, 2014; Accepted: November 11, 2014
}

\begin{abstract}
The experiment was conducted in order to study effects of seeds priming with gibberellic acid $\left(\mathrm{GA}_{3}\right)$ at $0,3,5$ and $8 \mathrm{mM}$ on germination, growth and antioxidant enzymes activity in alfalfa seedlings under salinity stress $(200 \mathrm{mM} \mathrm{NaCl})$. All control seeds germinated. The rate of germinated seeds was reduced to $48 \%$ in the presence of $\mathrm{NaCl}$, and increased to $76 \%$ after seeds priming with $5 \mathrm{mM} \mathrm{GA}_{3}$. Priming with $5 \mathrm{mM} \mathrm{GA}_{3}$ was also correlated with an increase of dry weight of seedlings derived from both stressed and non-stressed seeds as well as with the reduction of electrolyte leakage (EL) and malondialdehyde (MDA) level in salt stressed seedlings. The activity of superoxide dismutase, catalase, guaiacol peroxidase and ascorbate peroxidase in primed and non-primed seeds increased in the presence of $\mathrm{NaCl}$ and after priming of seeds with $5 \mathrm{mM} \mathrm{GA}_{3}$, whereas only small effect on glutathione reductase activity in both primed and non-primed seeds was observed. The total ascorbate level was higher in both stressed and non-stressed seedlings from primed seeds. These results suggest that $\mathrm{GA}_{3}$ priming might increase the salt tolerance of alfalfa seedlings through enhancing the activities of antioxidant enzymes and reducing the membrane damage as estimated using biomarkers, EL index and MDA content.
\end{abstract}

Key words: alfalfa, antioxidant enzymes, germination, gibberellic acid $\left(\mathrm{GA}_{3}\right)$ priming, salinity

\section{INTRODUCTION}

Germination of seeds, one of the most critical phases of plant life (Davies 1995), is greatly influenced by salinity (Záborszky et al. 2002). Salinity can affect germination and seedlings growth either by creating an osmotic pressure that prevents water uptake or by toxic effects of sodium and chloride ions (Reggiani et al. 1995). Salinity is also considered as a major abiotic stress and significant factor affecting crop production, especially in arid and semi-arid regions (Khajeh-Hosseini et al. 2003). For instance, decreased water uptake during imbibition and excessive uptake of ions were found to contribute to salt sensitivity during germination and seedling establishment in cowpea (Murillo-Amador et al. 2002).
The stability of cell membranes is considered for a long time as an indicator of plant resistance to stress (Farooq et al. 2006; Munns \& James 2003). Bandeoğlu et al. (2004) found that salt stress causes increase of malondialdehyde (MDA) production and cell membrane damage in leaf of rice seedlings.

Salt stress is always accompanied with an oxidative stress as a consequence of the generation of reactive oxygen species (ROS), such as superoxide ion, hydrogen peroxide and hydroxyl radicals, which are detrimental to plants survival. Elevated production of ROS can seriously disrupt cellular homeostasis and normal metabolisms through oxidative damage of lipids, proteins and nucleic acids (Barba-Espín et al. 2010). But plants are not defenseless. Under salt stress some defense mecha- 
nisms are initiated, which protect plants from harmful effects of oxidative stress. Reactive oxygen species (ROS) scavenging is one of such common defense response against abiotic stress (Vranova et al. 2002). The major ROS scavenging system includes a complex of enzymes as catalase (CAT), peroxidase (POD), superoxide dismutase (SOD) and glutathione reductase (GR).

Seed priming is an efficient method for increasing of seed vigor and improvement of germination and seedling growth (Parera \& Cantliffe 1994). This technique increases the environmental range suitable for germination, and provides faster and synchronous seedling emergence (Parera \& Cantliffe 1994).

Gibberellins are generally involved in growth and development. They control seed germination, leaf expansion, stem elongation and flowering. Gibberellic acid $\left(\mathrm{GA}_{3}\right)$ is the most active gibberellin and used often in germination (Groot \& Karssen 1987), but also $\mathrm{GA}_{4+7}$ plays the important role in this process (Kępczyński \& Białecka 1994).

Although priming improves the rate and uniformity of seedling emergence and growth, particularly under stress conditions (Murungu et al. 2005), the effectiveness of different priming agents varies under different stresses and among various crop species (Iqbal et al. 2006).

Alfalfa is an important agricultural species providing valuable protein for animal feed. It also plays an important role in horticulture as a rotation plant, used also in remediation of the lands after fruit tree orchards.

The purpose of this research was to improve the germination ability of seeds sown to sub-optimal growth conditions posed by soil salinity. The effect of seed priming with $\mathrm{GA}_{3}$ to mitigate salt stress effects on germination and growth of alfalfa seedlings in relation to changes in antioxidant activities was evaluated.

\section{MATERIALS AND METHODS}

The experiment was conducted in the Seed Laboratory of College of Agriculture, University of Tehran, Iran. The experimental treatments consisted of four gibberellic acid $\left(\mathrm{GA}_{3}\right)$ concentrations and two levels of salinity and were arranged as a factorial in completely randomised design. Each treatment was replicated four times.

Seeds of alfalfa cv. Bami were obtained from the Seeds and Plant Improvement Institute, Karaj, Iran. Seeds of the selected cultivar were sterilised in $2 \%$ sodium hypochlorite containing $4 \mathrm{ml}$ Tween 20 for 7-10 min and then washed several times with distilled water. They were subjected to priming with different $\mathrm{GA}_{3}$ concentrations $(0,3,5$ and $8 \mathrm{mM})$ for $24 \mathrm{~h}$ at room temperature. Primed seeds $(\mathrm{P})$ were air dried at room temperature. The control seeds were not primed (NP). Four replicates of 25 seeds were then placed in $10 \mathrm{~cm}$ Petri dishes with double-layer filter paper in the presence or the absence of $200 \mathrm{mM}$ $\mathrm{NaCl}$, and placed in an incubator in constant darkness at $25^{\circ} \mathrm{C}$. Germinated seeds were counted daily for up to 7 days. For dry weight measurements, the seedlings were dried in an oven at $70{ }^{\circ} \mathrm{C}$ for $48 \mathrm{~h}$.

\section{Membrane permeability (electrolyte leakage)}

Electrolyte leakage (EL) was determined as described by Quartacci (2002). Seven seedlings per treatment in four replicates were sampled. Fresh seedlings were placed in test tubes containing $25 \mathrm{ml}$ double-distilled water. After $1 \mathrm{~h}$ at room temperature, the initial electrical conductivity was measured using a digital conductometer. The samples were placed in liquid nitrogen and then returned in the same tube for one additional hour of shaking and the final electrical conductivity (EC2) was measured. EL was calculated using the formula:

$$
\mathrm{EL}=(\mathrm{EC} 1 / \mathrm{EC} 2) \times 100
$$

\section{Malondialdehyde (MDA) assay}

Malondialdehyde (MDA) content was determined on seven seedlings per treatment, following the method of Du and Bramlage (1992), and used to determine the level of lipid peroxidation. Ground tissue $(0.2 \mathrm{~g})$ was homogenised with $2 \mathrm{ml}$ of $0.1 \%$ trichloroacetic acid (TCA), and the crude extract preparation was centrifuged at $10000 \times \mathrm{g}$ for $20 \mathrm{~min}$. A mixture of TCA, thiobarbituric acid (TBA) $(1 \mathrm{ml})$ and an aliquot of the supernatant $(1 \mathrm{ml})$ was heated at $95^{\circ} \mathrm{C}$ for $30 \mathrm{~min}$. and then quickly cooled on ice for $5 \mathrm{~min}$. After cooling, the mixture was centrifuged, and the absorbance of the supernatant was measured at 400, 500 and $600 \mathrm{~nm}$. Thiobarbituric acid-reactive substances (TBARS) were measured as 
MDA, a degraded product of lipids. The concentration of MDA was calculated from the absorbance values using an extinction co-efficient of $155 \mathrm{mM} \cdot \mathrm{cm}^{-1}$.

\section{Determination of enzyme activity}

For enzyme activity analysis, seven seedlings per treatment in four replicates were sampled at harvest and pooled to assess enzyme activity. Seedlings of each treatment were homogenised with $5 \mathrm{ml}$ of extraction buffer containing $50 \mathrm{mM} \mathrm{K}$ phosphate buffer, $\mathrm{pH} 7.5,100 \mathrm{mM}$ ethylene diamine tetra-acetic acid (EDTA), 5\% polyvinyl pyrrolidone (PVP), $5 \%$ glycerol and $1 \mathrm{mM}$ dithiothreitol (DTT). The homogenate was centrifuged at $15000 \times \mathrm{g}$ for $15 \mathrm{~min}$, and the supernatant fraction was used for enzyme assays. All steps in the preparation of the enzyme extracts were performed at $4{ }^{\circ} \mathrm{C}$. Protein concentrations in them were determined by the method of Bradford (1976) using bovine serum albumin as a standard.

\section{Superoxide dismutase (SOD)}

The activity of superoxide dismutase (SOD) was estimated by measuring its ability to inhibit the photochemical reduction of nitro blue tetrazolium (NBT), according to Stewart and Bewley (1980). The reaction mixture $(3 \mathrm{ml})$ contained $13 \mathrm{mM}$ methionine, $75 \mathrm{mM}$ NBT, $100 \mathrm{mM}$ EDTA, $50 \mathrm{ml}$ of enzyme extract within $50 \mathrm{mM}$ phosphate buffer (pH 7.8). The reaction was started with $2 \mathrm{mM}$ riboflavin by exposing the cuvette to a $15-\mathrm{W}$ fluorescent tube for $10 \mathrm{~min}$. The absorbance of each reaction mixture was measured at $560 \mathrm{~nm}$. One unit of SOD activity was defined as the amount of enzyme, which causes $50 \%$ inhibition of the photochemical reduction of NBT.

\section{Catalase (CAT)}

Activities of catalase (CAT) were measured using the method of Chance and Maehly (1955) with modification. The CAT reaction solution $(3 \mathrm{ml})$ contained $50 \mathrm{mM}$ phosphate buffer $(\mathrm{pH} 7.0)$, $15 \mathrm{mM} \mathrm{H}_{2} \mathrm{O}_{2}$ and $0.1 \mathrm{ml}$ enzyme extract. Reaction was initiated by adding enzyme extract. Changes in absorbance of the reaction solution at $240 \mathrm{~nm}$ were read every $20 \mathrm{~s}$. One unit CAT activity was defined as an absorbance change of $0.01 \mathrm{unit} \cdot \mathrm{min}^{-1}$.

\section{Guaiacol peroxidase (GPX)}

Guaiacol peroxidase activity (GPX) was determined using guaiacol as an electron donor, with a reaction mixture containing $20 \mathrm{mM}$ phosphate buffer ( $\mathrm{pH}$ 5.6), and $30 \% \mathrm{H}_{2} \mathrm{O}_{2}$ according to Srinivas et al. (1999). The increase of absorbance, due to tetraguaiacol formation was recorded at $470 \mathrm{~nm}$. One unit of peroxidase activity catalyzes the oxidation of $1 \mu \mathrm{mol}$ of guaiacol.

\section{Ascorbate peroxidase (APX)}

For determination of APX activity, the sample was extracted with $5 \mathrm{ml}$ of ice-cold $100 \mathrm{mM}$ phosphate buffer ( $\mathrm{pH}$ 7.0) containing $1 \mathrm{mM} \mathrm{ASC}$ and $1 \mathrm{mM}$ EDTA, centrifuged at $15000 \times g$ at $4{ }^{\circ} \mathrm{C}$ for $15 \mathrm{~min}$, and determined as described by Chen and Wang (2002). The reaction mixture $(3 \mathrm{ml})$ contained $100 \mathrm{mM}$ phosphate buffer ( $\mathrm{pH} 7.0$ ), $5 \mathrm{mM}$ ASC, $0.3 \mathrm{mM} \mathrm{H}_{2} \mathrm{O}_{2}$ and $0.1 \mathrm{ml}$ enzyme extract. Absorbance decreased by 0.01 at $290 \mathrm{~nm}$ was defined as an activity unit during $1 \mathrm{~min} \cdot \mathrm{mg}^{-1}$ protein.

\section{Glutathione reductase (GR)}

For determination of GR activity, the sample was homogenised with $5 \mathrm{ml}$ of $0.1 \mathrm{M}$ Tricine- $\mathrm{NaOH}$ buffer (pH 7.8) and centrifuged at $15000 \mathrm{~g}$ at $4{ }^{\circ} \mathrm{C}$ for $15 \mathrm{~min}$. The supernatant was collected and diluted properly for determination of GR activity according to the method of Chen and Wang (2002). The reaction mixture $(1 \mathrm{ml})$ contained $1 \mathrm{mM}$ NADPH, $0.1 \mathrm{M}$ Tricine-NaOH buffer (pH 7.8), $5 \mathrm{mM}$ oxidised glutathione and $0.2 \mathrm{ml}$ enzyme extract. Absorbance decreased by 0.01 at $340 \mathrm{~nm}$ during $1 \mathrm{~min} \cdot \mathrm{mg}^{-1}$ protein was defined as an activity unit.

\section{Ascorbate determination}

Seven seedlings per treatment in four replicates were sampled for ascorbic acid (AA) assay as described by Kampfenkel et al. (1995). The aliquots of the fresh material $(0.25 \mathrm{~g})$ were homogenised in ice-cold $6 \%(\mathrm{w} / \mathrm{v})$ TCA, using a cold mortar and pestle. Total and reduced ascorbate (AsA) was determined in the supernatant after centrifugation at $15000 \times g$ for $10 \mathrm{~min}$ at $4{ }^{\circ} \mathrm{C}$. A red colour resulted from the complex of bipyridine and $\mathrm{Fe}^{2+}$ caused by reduction of $\mathrm{Fe}^{3+}$ to $\mathrm{Fe}^{2+}$ by ascorbic acid and was measured at $525 \mathrm{~nm}$. Total ascorbate was determined through a reduction of dehydroascorbate 
(DHA) to AsA by $10 \mathrm{mM}$ DTT. Excess DTT was removed with N-ethylmaleimide (NEM) 4\% (w/v). A standard curve covering the range of 10 to $50 \mu \mathrm{mol} \mathrm{AA}$ was used.

Analysis of variance using the Statistical Analysis System computer package (SAS Institute Inc. 1988) was performed. When significant treatment effects were found, the LSD test was applied to make comparisons among the means at the 0.05 level of significance (Steel \& Torrie 1960).

\section{RESULTS AND DISCUSSION}

The salinity caused by $200 \mathrm{mM} \mathrm{NaCl}$ was correlated with reduction of the germination percentage and dry weight of both primed and non-primed seeds (Table 1). Similar results were obtained for some other plants, like melon (Sivritepe et al. 2003), canola (Farhoudi et al. 2007) and maize (Bakhtet al. 2011). However, priming reduced this adverse effect. The germination percentage and dry weight were higher within the seedlings from seeds primed with $\mathrm{GA}_{3}$ than in non-primed ones. The most beneficial impact on germination was obtained after priming with $5 \mathrm{mM} \mathrm{GA}_{3}$. For this reason, only this $\mathrm{GA}_{3}$ concentration was chosen to analyse the effect of sodium salt on enzymatic activities at $200 \mathrm{mM}$ $\mathrm{NaCl}$ and control, seven days after sowing.

Exogenous application of $\mathrm{GA}_{3}$ was previously reported to increase the seed germination rate al-

Table 1. The effect of seeds priming with $\mathrm{GA}_{3}$ and salt stress on germination and seedlings dry weight of Medicago sativa 'Bami'

\begin{tabular}{lcccc}
\hline $\begin{array}{c}\mathrm{NaCl} \\
(\mathrm{mM})\end{array}$ & 0 & $\begin{array}{c}3 \mathrm{mM} \\
\mathrm{GA}_{3}\end{array}$ & $\begin{array}{c}5 \mathrm{mM} \\
\mathrm{GA}_{3}\end{array}$ & $\begin{array}{c}8 \mathrm{mM} \\
\mathrm{GA}_{3}\end{array}$ \\
\hline \multicolumn{5}{c}{ Final germination percentage } \\
\hline 0 & $100 \mathrm{a}$ & $100 \mathrm{a}$ & $100 \mathrm{a}$ & $100 \mathrm{a}$ \\
200 & $48 \mathrm{c}$ & $51 \mathrm{c}$ & $72 \mathrm{~b}$ & $66 \mathrm{~b}$ \\
\hline \multicolumn{5}{c}{ Seedlings dry weight $(\mathrm{g})$} \\
\hline 0 & $0.035 \mathrm{c}$ & $0.035 \mathrm{c}$ & $0.055 \mathrm{a}$ & $0.043 \mathrm{~b}$ \\
\hline
\end{tabular}

Different letters represent significant differences $(p<0.05)$ between treatments at each column mond species (Zeinalabedini et al. 2009). Our results indicated that seed priming may be helpful in reducing the risk of poor germination and permit more uniform seedling growth under saline condition. Seed priming with $\mathrm{GA}_{3}$ might cause acceleration of metabolic reactions before germination and made germination of seeds possible under salinity stress (Wang et al. 2014). From our study it can be concluded that the priming of seeds with GA could limit the inhibiting effect of salinity on germination and seedling growth of alfalfa.

A consequence of salt-stress on plants is generation of excessive reactive oxygen species (ROS) such as superoxide, hydrogen peroxide and hydroxyl radicals (Masood et al. 2006). These radicals can damage vital cellular macromolecules. In this study, the extent of membrane damage in alfalfa seedlings was estimated by MDA and EL levels. In the absence of sodium salt, MDA levels were similar in NP and P seedlings (Table 2). In NP seeds, MDA content increased 1.3-fold in the presence of $200 \mathrm{mM} \mathrm{NaCl}$. However, MDA level decreased 1.9-fold in $\mathrm{P}$ seeds as compared to control $(0 \mathrm{mM} \mathrm{NaCl})$.

The EL index had similar value in not stressed and stressed seedlings after seven days of germination, but it decreased significantly in $P$ seeds. These results suggest that $\mathrm{GA}_{3}$ priming might have alleviated the membrane damage induced by salt.

Table 2. Effect of seeds priming with $\mathrm{GA}_{3}$ and salt stress at germination on malondialdehyde (MDA) content and electrolyte leakage (EL) of Medicago sativa' Bami' seedlings

\begin{tabular}{lccc}
\hline $\begin{array}{r}\mathrm{NaCl} \\
(\mathrm{mM})\end{array}$ & $\begin{array}{c}\mathrm{GA}_{3} \\
(\mathrm{mM})\end{array}$ & $\begin{array}{c}\text { MDA } \\
\left(\mu \mathrm{mol} \mathrm{g}{ }^{-1} \mathrm{FW}\right)\end{array}$ & EL $(\%)$ \\
\hline 0 & $0(\mathrm{NP})$ & $5.6 \mathrm{~b}$ & $78 \mathrm{~b}$ \\
& $5(\mathrm{P})$ & $5.1 \mathrm{~b}$ & $76 \mathrm{~b}$ \\
\hline 200 & $0(\mathrm{NP})$ & $7.2 \mathrm{a}$ & $74 \mathrm{~b}$ \\
& $5(\mathrm{P})$ & $3.8 \mathrm{c}$ & $43 \mathrm{a}$ \\
\hline
\end{tabular}

Different letters represent significant differences $(p<0.05)$ between treatments at each column 
To determine the response of alfalfa to salt-induced oxidative stress, SOD, CAT, GPX, APX, GR activities and AsA contents were measured in seedlings grown with or without $200 \mathrm{mM} \mathrm{NaCl}$. It was stated that there were no significant differences in GPX activity between both NP and P seeds grown under non- $\mathrm{NaCl}$ conditions (Table 3). GPX activities in the seedlings from NP seeds and $\mathrm{P}$ seeds treated with $200 \mathrm{mM} \mathrm{NaCl}$, were 1.2- and 1.5-fold higher respectively, than those measured in control seedlings under non-salt control conditions.

The seedlings from $P$ seeds had the higher activity of CAT, SOD, APX and GR than these from the NP seeds (Tables $3 \& 4$ ). Salinity caused an increase of the specific total CAT, SOD and APX activities in both NP and P seeds, compared with their control groups, whereas it had little effect on GR activity (Tables $3 \& 4$ ).
When plants are subjected to saline stress, activities of a number of antioxidant enzymes are enhanced in order to eliminate ROS (Ruiz-Lozano 2003). It is well known that SOD converts $\mathrm{O}_{2}{ }^{-}$into $\mathrm{H}_{2} \mathrm{O}_{2}$, which is then eliminated by CAT (Reddy et al. 2004). CAT is an important antioxidant enzyme that converts $\mathrm{H}_{2} \mathrm{O}_{2}$ to water in peroxysomes (Fridovich 1995). In this organelle, $\mathrm{H}_{2} \mathrm{O}_{2}$ is produced from $\beta$ oxidation of fatty acids and photorespiration $(\mathrm{By}-$ bordi 2012). Higher activity of CAT and APX decreases $\mathrm{H}_{2} \mathrm{O}_{2}$ level in the cells providing protection for membranes, mainly in the chloroplasts, because several enzymes of the Calvin cycle are extremely sensitive to $\mathrm{H}_{2} \mathrm{O}_{2}$. A high level of $\mathrm{H}_{2} \mathrm{O}_{2}$ directly inhibits $\mathrm{CO}_{2}$ fixation (Yamazaki et al. 2003). APX along with GR are two pivotal enzymes in the cycle ASC-GSH (Polle 2001), which functions to remove $\mathrm{H}_{2} \mathrm{O}_{2}$. However, in the present investigation, salinity did not cause the GR activity increasing in seedlings.

Table 3. Effect of seeds $\mathrm{GA}_{3}$ priming and salt stress at germination on superoxide dismutase (SOD), catalase (CAT), guaiacol peroxidase (GPX) activities in Medicago sativa 'Bami' seedlings

\begin{tabular}{ccccc}
\hline $\begin{array}{c}\mathrm{NaCl} \\
(\mathrm{mM})\end{array}$ & $\begin{array}{c}\mathrm{GA}_{3} \\
(\mathrm{mM})\end{array}$ & $\begin{array}{c}\mathrm{SOD} \\
\left(\text { units } \cdot \mathrm{mg}^{-1} \mathrm{pro}-\right. \\
\left.\text { tein } \cdot \mathrm{min}^{-1} \pm \mathrm{SD}\right)\end{array}$ & $\begin{array}{c}\mathrm{CAT} \\
\left(\text { units } \cdot \mathrm{mg}^{-1} \text { pro- }\right. \\
\left.\text { tein } \cdot \mathrm{min}^{-1} \pm \mathrm{SD}\right)\end{array}$ & $\begin{array}{c}\text { GPX } \\
(\mathrm{n} \mathrm{mol} \mathrm{tetra-guaiacol} \\
\left.\text { formed } \cdot \mathrm{min}^{-1} \cdot \mathrm{g}^{-1} \mathrm{FW} \pm \mathrm{SD}\right)\end{array}$ \\
\hline \multirow{2}{*}{ Control $(0)$} & $0(\mathrm{NP})$ & $18.46 \pm 0.18 \mathrm{c}$ & $8.56 \pm 0.66 \mathrm{~d}$ & $410.28 \pm 2.12 \mathrm{c}$ \\
& $5(\mathrm{P})$ & $24.12 \pm 1.16 \mathrm{~b}$ & $16.43 \pm 1.35 \mathrm{~b}$ & $427.84 \pm 1.26 \mathrm{c}$ \\
\hline \multirow{2}{*}{200} & $0(\mathrm{NP})$ & $23.57 \pm 1.83 \mathrm{~b}$ & $11.73 \pm 0.15 \mathrm{c}$ & $516.6 \pm 2.16 \mathrm{~b}$ \\
& $5(\mathrm{P})$ & $38.34 \pm 0.43 \mathrm{a}$ & $23.16 \pm 1.73 \mathrm{a}$ & $632.3 \pm 1.23 \mathrm{a}$ \\
\hline
\end{tabular}

Results represent the average of four replicates \pm SD. Different letters represent significant differences $(p<0.05)$ between treatments at each column

Table 4. Effect of seeds priming with $\mathrm{GA}_{3}$ and salt stress at germination on ascorbate peroxidase (APX) and glutathione reductase (GR) activities in Medicago sativa 'Bami' seedlings

\begin{tabular}{rccc}
\hline $\begin{array}{c}\mathrm{NaCl} \\
(\mathrm{mM})\end{array}$ & $\begin{array}{c}\mathrm{GA}_{3} \\
(\mathrm{mM})\end{array}$ & $\begin{array}{c}\text { APX } \\
\left(\text { units } \cdot \mathrm{mg}^{-1} \mathrm{protein} \cdot \mathrm{min}^{-1} \pm \mathrm{SD}\right)\end{array}$ & $\begin{array}{c}\text { GR } \\
\left(\text { units } \cdot \mathrm{mg}^{-1} \mathrm{protein}_{\mathrm{min}}{ }^{-1} \pm \mathrm{SD}\right)\end{array}$ \\
\hline Control $(0)$ & $0(\mathrm{NP})$ & $11.45 \pm 0.45 \mathrm{~d}$ & $12.37 \pm 0.55 \mathrm{~b}$ \\
& $5(\mathrm{P})$ & $17.10 \pm 1.28 \mathrm{c}$ & $19.65 \pm 1.11 \mathrm{a}$ \\
\hline 200 & $0(\mathrm{NP})$ & $21.83 \pm 1.47 \mathrm{~b}$ & $12.65 \pm 0.93 \mathrm{~b}$ \\
& $5(\mathrm{P})$ & $32.14 \pm 0.23 \mathrm{a}$ & $20.07 \pm 0.47 \mathrm{a}$ \\
\hline
\end{tabular}

Note: see Table 3 
Table 5. Effect of seeds priming with $\mathrm{GA}_{3}$ and salt stress at germination on ascorbic acid (AA), AA+dehydroascorbate (DHA) and AA/DHA contents in Medicago sativa 'Bami' seedlings

\begin{tabular}{rccr}
\hline $\begin{array}{r}\mathrm{NaCl} \\
(\mathrm{mM})\end{array}$ & $\begin{array}{c}\mathrm{GA}_{3} \\
(\mathrm{mM})\end{array}$ & $\begin{array}{c}\mathrm{AA} \\
\left(\mu \mathrm{mol} \cdot \mathrm{g}^{-1} \mathrm{FW}\right)\end{array}$ & $\begin{array}{c}\mathrm{AA}+\mathrm{DHA} \\
\left(\mu \mathrm{mol} \cdot \mathrm{g}^{-1} \mathrm{FW}\right)\end{array}$ \\
\hline Control $(0)$ & $0(\mathrm{NP})$ & $0.27 \pm 0.43 \mathrm{~b}$ & $0.3 \pm 1.52 \mathrm{~d}$ \\
& $5(\mathrm{P})$ & $0.63 \pm 0.16 \mathrm{a}$ & $1.6 \pm 0.68 \mathrm{~b}$ \\
\hline 200 & $0(\mathrm{NP})$ & $0.35 \pm 1.24 \mathrm{~b}$ & $0.85 \pm 0.26 \mathrm{c}$ \\
& $5(\mathrm{P})$ & $0.78 \pm 0.38 \mathrm{a}$ & $2.11 \pm 0.62 \mathrm{a}$ \\
\hline
\end{tabular}

Note: see Table 3

Furthermore, we observed that enzyme activities in NP seeds were not high enough for the complete scavenging of $\mathrm{H}_{2} \mathrm{O}_{2}$, although their activities increased with $\mathrm{NaCl}$ treatment. On the other hand, activity of enzymes increased in the seedlings from $\mathrm{P}$ seeds compared to the control suggesting a negative relationship between antioxidant enzyme activity and MDA, what confirms Esfandiari et al. (2008) and Shao et al. (2005) results.

In this study, MDA accumulation, which represents the level of lipid peroxidation and thus, the accumulation of ROS, was also reduced under $\mathrm{GA}_{3}$ priming associated with an increase in activities of CAT, SOD, GPX and APX. Mansour (1998) reported that reduced membrane damage of onion leaf tissues under salinity stress could be explained by a reduction in concentrations of $\mathrm{H}_{2} \mathrm{O}_{2}$ and MDA. Furthermore, the induction of antioxidant enzymes in $\mathrm{GA}_{3}$-primed seeds correlated with a decrease in MDA content, suggesting a membrane protection under salt stress conditions.

In this study, the seedlings from seeds primed with $5 \mathrm{mM} \mathrm{GA}_{3}$ exhibited a greater accumulation of AsA than those from non-primed both from control and under $\mathrm{NaCl}$ conditions (Table 5). The $\mathrm{NaCl}$ treatment had no effect on the total ascorbate content, or the AsA/DHA ratio in non-primed and primed seeds.

There is evidence that seeds priming of most agricultural and horticultural crops led to improvement of germination and seedlings establishment, their growth and development, which is in correlation with efficient water uptake (Parera \& Cantliffe 1994).

In the present study, $\mathrm{GA}_{3}$ priming of alfalfa 'Bami' seeds resulted in increased germination percentage and seedlings growth, decreased lipid peroxidation and enhanced antioxidant defenses, and may be an efficient method to overcome seed germination problems and to improve seedlings growth in the field, especially under salinity conditions. The study on potential effects of $\mathrm{GA}_{3}$ priming persisting on the later growth and development stages are in progress in our laboratory.

\section{REFERENCES}

Bakht J., Shafi M., Jamal Y., Sher H. 2011. Response of maize (Zea mays L.) to seed priming with $\mathrm{NaCl}$ and salinity stress. Span. J. Agric. Res. 9(1): 252-261. DOI: 10.5424/sjar/20110901-113-10.

Bandeoğlu E., Eyidoğan F., Yücel M., Öktem H.A. 2004. Antioxidant responses of shoots and roots of lentil to NaCl-salinity stress. Plant Growth Regul. 42(1): 6977. DOI: 10.1023/b:grow.0000014891.35427.7b.

Barba-Espín G., Diaz-Vivancos P., Clemente-Moreno M.J., Albacete A., Faize L., Faize M., et al. 2010. Interaction between hydrogen peroxide and plant hormones during germination and the early growth of pea seedlings. Plant Cell Environ. 33(6): 981-994. DOI: $10.1111 / \mathrm{j} .1365-3040.2010 .02120 . x$.

Bradford M.M. 1976. A rapid and sensitive method for quantitation of microgram of protein utilizing the principle of protein-dye binding. Anal. Biochem. 72(1-2): 248-254. DOI: $10.1016 / 0003-$ 2697(76)90527-3.

Chance B., Mackley A.C. 1955. Assay of catalases and peroxidases. Meth. Enzymol. 2: 764-775. DOI: 10.1016/s0076-6879(55)02300-8.

Chen J.X., Wang X.F. 2002. Experimental Instruction of Plant Physiology. South China University of Technology Press, Guangzhou, p. 124.

Davies P.J. 1995. Plant Hormones. Physiology, biochemistry and molecular biology. Dordrecht: Kluwer Academic Publishers. pp. 1-38. DOI: 10.1007/97894-011-0473-9. 
Du Z., Bramlage W.J. 1992. Modified thiobarbituric acid assay for measuring lipid oxidation in sugar-rich plant tissue extracts. J. Agric. Food Chem. 40(9): 1566-1570. DOI: 10.1021/jf00021a018.

Esfandiari E., Shakiba M.R., Mahboob S., Alyari H., Shahabivand S. 2008. The effect of water stress on the antioxidant content, protective enzyme activities, proline content and lipid peroxidation in wheat seedling. Pakistan Journal of Biological Science 11(15): 1916-1922. DOI: 10.3923/pjbs.2008.1916.1922.

Bybordi A. 2012. Effect of ascorbic acid and silicium on photosynthesis, antioxidant enzyme activity, and fatty acid contents in canola exposure to salt stress. Journal of Integrative Agriculture 11(10): 16101620. DOI: 10.1016/s2095-3119(12)60164-6.

Farhoudi R., Sharifzadeh F., Poustini K., Makkizadeh M.T., Kochak Por M. 2007. The effects of $\mathrm{NaCl}$ priming on salt tolerance in canola (Brassica napus) seedlings grown under saline conditions. Seed Sci. Technol. 35(3): 754-759. DOI: 10.15258/sst.2007.35.3.23.

Farooq M., Basra S.M.A., Hafeez K. 2006. Seed invigoration by osmohardening in coarse and fine rice. Seed Science and Technology 34(1): 181-187. DOI: 10.15258/sst.2006.34.1.19.

Fridovich I. 1995. Superoxide radical and superoxide dismutases. Ann. Rev. Biochem. 64(1): 97-112. DOI: 10.1146/annurev.biochem.64.1.97.

Groot S.P.C., Karssen C.M. 1987. Gibberellins regulate seed germination in tomato by endosperm weakening: a study with gibberellin-deficient mutants. Planta 171(4): 525-531. DOI: 10.1007/BF00392302.

Reggiani R., Bertani A., Bozo S. 1995.The effect of salinity on early seedling growth of seeds of three wheat (Triticum aestivum L.) cultivars. Can. J. Plant Sci. 75(1): 175-177. DOI: 10.4141/cjps95-029.

Iqbal M., Ashraf M., Jamil A., Ur-Rehman S. 2006. Does seed priming induce changes in the levels of some endogenous plant hormones in hexaploid wheat plants under salt stress. Journal of Integrative Plant Biology 48(2): 181-189. DOI: 10.1111/j.17447909.2006.00181.x.

Kampfenkel K., Van Montagu M., Inzé D. 1995. Extraction and determination of ascorbate and dehydroascorbate from plant tissue. Anal. Biochem. 225(1): 165-167. DOI: 10.1006/abio.1995.1127.

Kępczyński J., Białecka B. 1994. Stimulatory effect of ethephon, ACC, gibberellin A3 and A47+7 on germination of methyl jasmonate inhibited Amaranthus caudatus L. seeds. Plant Growth Regul. 14(3): 211-216. DOI: 10.1007/BF00024795.
Khajeh-Hosseini M., Powell A.A., Bingham I.J. 2003. The interaction between salinity stress and seed vigour during germination of soybean seeds. Seed Sci. Technol. 31(3): 715-725. DOI: 10.15258/sst.2003.31.3.20.

Mansour M.M.F. 1998. Protection of plasma membrane of onion epidermal cells by glycinebetaine and proline against $\mathrm{NaCl}$ stress. Plant Physiol. Biochem. 36(10): 767-772. DOI: 10.1016/s0981-9428(98)80028-4.

Masood A., Shah N.A., Zeeshan M., Abraham G. 2006. Differential response of antioxidant enzymes to salinity stress in two varieties of Azolla (Azolla pinnata and Azolla filiculoides). Env. Exp. Bot. 58(1-3): 216-222. DOI: 10.1016/j.envexpbot.2005.08.002

Munns R., James R.A. 2003. Screening methods for salinity tolerance: a case study with tetraploid wheat. Plant Soil. 253(1): 201-218. DOI: 10.1023/a:1024553303144.

Murillo-Amador B., López-Aguilar R., Kaya C., LarrinagaMayoral J., Flores-Hernández A. 2002. Comparative effects of $\mathrm{NACl}$ and polyethylene glycol on germination, emergence and seedling growth of cowpea. Journal of Agronomy and Crop Science 188: 235-247. DOI: 10.1046/j.1439-037X.2002.00563.x.

Murungu F.S., Nyamugafata P., Chiduza C., Clark L.J., Whalley W.R. 2005. Effects of seed priming and water potential on germination of cotton (Gossypium hirsutum L.) and maize (Zea mays L.) in laboratory assays. South African J. Plant Soil 22(1): 64-70. DOI: $10.1080 / 02571862.2005 .10634683$.

Parera C.A., Cantliffe D.J. 1994. Presowing seed priming. In: Janick J. (Ed.), Horticultural Reviews, Vol. 16 John Wiley \& Sons, Inc., Oxford, UK. DOI: $10.1002 / 9780470650561 . c h 4$.

Polle A. 2001. Dissecting the superoxide dismutaseascorbate-glutathione-pathway in chloroplasts by metabolic modeling. Computer simulations as a step towards flux analysis. Plant Physiology 126(1): 445-462. DOI: 10.1104/pp.126.1.445.

Quartacci M.F, Glišić O., Stevanović B., Navari-Izzo F., 2002. Plasma membrane lipids in the resurrection plant Ramonda serbica following dehydration and rehydration. J. Exp. Bot. 53(378): 2159-2166. DOI: 10.1093/jxb/erf076.

Reddy A.R., Chaitanya K.V., Jutur P.P., Sumithra K. 2004. Differential antioxidative responses to water stress among five mulberry (Morus alba L.) cultivars. Environmental and Experimental Botany 52(1): 33-42. DOI: 10.1016/j.envexpbot.2004.01.002.

Ruiz-Lozano J.M. 2003. Arbuscular mycorrhizal symbiosis and alleviation of osmotic stress. New perspectives for molecular studies. Mycorrhiza 13(6): 309317. DOI: 10.1007/s00572-003-0237-6. 
Shao H.B., Liang Z.S., Shao M.A. 2005. Changes of anti-oxidative enzymes and MDA content under soil water deficits among 10 wheat (Triticum aestivum L.) genotypes at maturation stage. Colloids and Surfaces. B. Biointerfaces 45(1): 7-13. DOI: 10.1016/j.colsurfb.2005.06.016.

Sivritepe N., Sivritepe H.O., Eris A. 2003. The effect of $\mathrm{NaCl}$ priming on salt tolerance in melon seedlings grown under saline conditions. Sci. Hortic. 97(3-4): 229-237. DOI: 10.1016/s0304-4238(02)00198-X.

Srinivas N.D., Rashmi K.R., Raghavarao K.S. 1999. Extraction and purification of a plant peroxidase by aqueous two-phase extraction coupled with gel filtration. Process Biochemistry 35(1-2): 43-48. DOI: 10.1016/s0032-9592(99)00030-8.

Steel R.G.D., Torrie J.H. 1960. Principles and procedures of statistics. (With special Reference to the Biological Sciences.) McGraw-Hill Book Company, New York, Toronto, London. Biometrische Zeitschrift 1962 4(3) 207-208. DOI: 10.1002/bimj.19620040313.

Stewart R.R.C., Bewley J.D. 1980. Lipid peroxidation associated with accelerated aging of soybean axes. Plant Physiol. 65(2): 245-248. DOI: 10.1104/pp.65.2.245.
Wang L., Mu C., Du M., Chen Y., Tian X., Zhang M., Li Z. 2014. The effect of mepiquat chloride on elongation of cotton (Gossypium hirsutum L.) internode is associated with low concentration of gibberellic acid. Plant Science 225: 15-23. DOI: 10.1016/j.plantsci.2014.05.005.

Vranova E., Inze D., Van Brensegem F. 2002. Signal transduction during oxidative stress. J. Exp. Bot. 53(372): 1227-1236. DOI: $10.1093 /$ jexbot/53.372.1227.

Yamazaki J., Ohashi A., Hashimoto Y., Negishi E., Kumagai S., Kubo T., et al. 2003. Effects of high light and low temperature during harsh winter on needle photodamage of Abies mariesii growing at the forest limit on Mt. Norikura in Central Japan. Plant Science 165(1): 257-264. DOI: 10.1016/s0168-9452(03)00169-9.

Záborszky S., Nagy E., Szőke C. 2002. Effect of seed treatment on the emergence of inbred lines of maize (Zea mays L.). Acta Agronomica Hungarica 50(3): 359-369. DOI: 10.1556/aagr.50.2002.3.13.

Zeinalabedini M., Majourhat K., Khayam-Nekoui M., Hernández J.A., Martínez-Gómez P. 2009. Breaking seed dormancy in long-term stored seeds from Iranian wild almond species. Seed Sci. Technol. 37(2): 267-275. DOI: 10.15258/sst.2009.37.2.01. 